\title{
MAGNETNA REZONANTNA TOMOGRAFIJA - SISTEMSKI PRIKAZ I NOVE METODE U DIJAGNOSTICI
}

\section{MAGNETIC RESONANCE IMAGING - SYSTEM REVIEW AND NEW DIAGNOSTIC METHODS}

\author{
Jelena Ećimović, Fakultet tehničkih nauka, Novi Sad
}

\begin{abstract}
Oblast - BIOMEDICINSKO INŽENJERSTVO
Kratak sadržaj - U radu je prikazana istorija MRI, sekvence i ključni elementi implementacije u uređajima za magnetnu rezonantnu tomografiju kao $i$ njene prednosti $i$ ograničenja. Takođe, opisana su kontrastna sredstva $i$ nove metode u dijagnostici.
\end{abstract}

Ključne reči : Biomedicinska instrumentacija, Magnetna rezonacija, Tomografija, MRI

Abstract - The paper contains the history of MRI, sequences and key implementation elements in magnetic resonance imaging devices, as well contains advantages and limitations. Also, contrast media and new methods of diagnostics are described.

Key words: Biomedical instrumentation, Magnetic resonance, Tomography, MRI

\section{UVOD}

Rezonancija je svugdje prisutni fenomen u prirodi. Svaki put kada je sistem sa neutralnom frekvencijom izložen spoljašnjim periodičnim poremećajima frekvencije koja je blizu prirodnoj frekvenciji događa se snažno povećavanje opsega vibracija. Ako se čestica sa magnetnim dipolnim momentom istovremeno postavi u statičko magnetno polje i u oscilatorno magnetno polje sa odgovarajućom frekvencijom može se dogoditi rezonantna apsorpcija / rezonantna emisija. Rezonantne pojave su zasnovane na sposobnosti materijala koji se nalazi u konstantnom magnetnom polju da selektivno apsorbuje spoljašnje (visokofrekventno) elektromagnetno zračenje.

MRI se zasniva na kretanju protona (malog magnetnog dipola sa sjevernim i južnim polom) iz jezgra vodonika, koji sadrži tzv. magnetni moment ili spin. Ljudsko tijelo se sastoji od $63 \%$ atoma vodonika. Atom vodonika emituje za MRI signale, koji prikazuje sliku, uglavnom zahvaljujući signalima iz njegovog jezgra. U svakoj ćeliji se nalaze molekuli vode. Svaki molekul vode sastoji se od jednog atoma kiseonika i dva atoma vodonika, a svaki atom vodonika sadrži samo jedan proton. Atomska jezgra elemenata sa neparnim brojem protona (kao što je vodonik) i/ili neutrona posjeduju mehanički moment (spin) i njemu pridruženi magnetni moment, koji se može predstaviti i kao slabo magnetno polje, koje emituje signale za MRI.

\section{NAPOMENA:}

Ovaj rad proistekao je iz master rada čiji mentor je bio dr Platon Sovilj, vanr. prof.
Kako spin posjeduje i mehanički moment, on se ponaša i kao čigra koju spoljašnje magnetsko polje ne može potpuno da orijentiše već ga navodi na precesiono kretanje i u spoljašnjem magnetnom polju spin precesuje oko pravca polja nagnut pod određenim uglom. Pri čemu je precesiona frekvencija jednaka rezonantnoj frekvenciji.

Fenomen nuklearne magnetne rezonance je 1938. godine uočio Isidor Rabi u eksperimentu sa snopovima atoma $\mathrm{i}$ elektromagnetnim zračenjem. 1945. godine Felix Bloch, William Hansen i Martin Packard, Edward Purcell, Robert Pound i Henry Torrey pokazali da jako magnetno polje prouzrokuje razdvajanje energetskih nivoa i da pod određenim uslovima jezgra atoma rezonuju u rasponu radiofrekventnih talasa, emitujući radiofrekventni signal koji se može detektovati. 1952. godine F. Bloch i E. Purcell su dobili Nobelovu nagradu za fiziku. Bitno je napomenuti da je 1984. godine Američko udruženje radiologa, da bi uklonilo asocijaciju na nuklearne reakcije i bombe, iz naziva metode izostavilo pridjev nuklearna pa je u medicini NMR poznat kao imidzing magnetnom rezonancom - MRI (od naziva na engleskom magnetic resonance imaging).

\section{STRUKTURA UREĐAJA I SEKVENCE MAGNETNE REZONANCE}

\subsection{Struktura uređaja}

Da bi se obezbijedili potrebni uslovi za stvaranje, detektovanje MR signala $\mathrm{u}$ tkivu i rekonstrukcija MR slika, MR uređaj mora da ima:

- Izvor homogenog magnetnog polja $\mathrm{B}_{0}$, koje će biti stvoreno u prostoru dovoljno velikom da prihvati torzo pacijenta.

- Podsistem za stvaranje gradijentnog magnetnog polja koje služi za selekciju presjeka i pozicioniranje MR signala unutar ravni presjeka.

- Radio-frekventni (RF) podsistem koji treba da vrši emisiju radiofrekventnih impulsa i na taj način se vektor magnetizacije protona izvodi iz ravnotežnog položaja. RF podsistem treba da vrši i prijem MR signala.

- Računar koji vrši procesuiranje detektovanih MR signala, rekonstrukciju, memorisanje i prikaz slike, a takođe, treba da vrši i sinhronizaciju rada svih podsistema MR uređaja.

Funkcionisanje aparata zahtjeva generisanje tri vrste elektromagnetnih polja: statičkog magnetnog polja, gradijentnog elektromagnetnog polja i oscilatornog elektromagnetnog polja. $\mathrm{Za}$ generisanje glavnog polja 
manje snage u MR se koriste permanentni magneti, dok se za generisanje polja veće snage koriste elektromagneti i to sa otpornim ili superprovodnim namotajima. Zbog intenziteta jednosmjerne struje velike snage (40 do 100 kW) koja prolazi kroz namotaje elektromagneta dolazi do oslobađanja velike količine toplote, pa MR uređaji kod kojih se glavno polje $\mathrm{B}_{0}$ stvara otpornim magnetom moraju imati sistem za hlađenje (uobičajeno je vodeno hlađenje).

Prema jačini magnetnog polja MRI uređaji se dijele na:

- Uređaji sa slabim magnetnim poljem jačine od $0.15 \mathrm{~T}$ do $0.5 \mathrm{~T}$

- Uređaji sa srednjim magnetnim poljem jačine od $0.5 \mathrm{~T}$ do $1 \mathrm{~T}$

- Uređaji sa jakim magnetnim poljem jačine od 1 $\mathrm{T}$ do $3 \mathrm{~T}$

U zavisnosti od svrhe primjene, aparati sa slabim i jakim magnetnim poljem imaju svoje prednosti i mane, ali to ne znači da su jača polja uvijek bolja. Aparati sa snažnim magnetnim poljem omogućavaju bolju prostornu rezoluciju i brzu dinamičku MR spektroskopiju pacijenata.

Kontrast snimaka tkiva je kod aparata sa slabijim magnetnim poljem bolji, a imaju i značajno niže operativne troškove. Sami magneti moraju da budu odvojeni od okruženja, budući da jaka magnetna polja mogu negativno da utiču na osjetljivu elektronsku opremu, ali i na same ispitanike.

Takođe, uređaj mora da bude odvojen od uticaja spoljašnje sredine, naročito od širokog opsega radio talasa, kako bi se izbjegle smetnje. Zato je cijeli sistem smješten u tzv. Faradejev kavez

\subsection{Sekvence Magnetne rezonance}

Prednost magnetne rezonance nad drugim metodama dobijanja podataka je što MRI posjeduje niz načina snimanja tkiva.

Tehnike korištenja samog spina:

- SE (spin-echo) - najjednostavniji je način snimanja. To je dvostepeni proces, gdje longitudinalni oporavak određuje početni intenzitet za transverzalno opadanje.

- FSE (fast spin-echo) - tehnika kod koje se $\mathrm{T}_{2}$ snimak izrađuje prije vremena, radi ubrzavanja cjelokupnog procesa (inače bi, korištenjem SE tehnike, dobivanje $\mathrm{T}_{2}$ snimka zahtijevalo i do 12 minuta na uređaju jačine $1 \mathrm{~T}$ ).

- IR (inversion recovery) - posebna je metoda uzimanja $\mathrm{T}_{1}$ snimka, koja daje kvalitetnije rezultate (veći kontrast i poboljšano razlikovanje tkiva prema određenim karakteristikama obično količini vode). Prije samog snimanja tkivo se pripremi primjenom dodatnog signala.

- $\quad$ FLAIR (fluid attenuated inversion recovery) posebna varijanta IR tehnike snimanja u kojoj se signal vode potiskuje, ali na drugačiji način od klasičnih $\mathrm{T}_{1}$ snimaka. Rezultantni snimci su korisne pri otkrivanju promjena u moždanom tkivu (ožiljci, otoci tkiva, itd.).
- $\quad$ STIR (short tau inversion recovery) - varijanta $\mathrm{T}_{1}$ snimka u kojoj se potiskuje signal masti.

Budući da $T_{1}$ snimci sadrže većinom signale masti, rezultantne slike su vrlo tamne, što pogoduje prikazivanju metastaza, otoka, ožiljaka.

Tehnike korištenjem gradijenta:

- CISS (constructive interference steady state) vrlo brza gradijentna metoda dobra kod snimanja brzih kretnji, na primjer rada srca.

- DWI (diffusion weighted imaging) - tehnika koja nastoji poništiti sav signal iz tkiva, nakon čega će ostati vidljiv samo signal molekula koje se kreću zbog efekta difuzije. Zbog velike zahtjevnosti samo uređaji sa snažnim i brzim gradijentima mogu uspješno provoditi tehniku DWI.

Ostale tehnike:

- DTI (diffusion tensor imaging) - tehnika koja snima difuziju uzduž neuronskih vlakana radi dobivanja podataka o toku snopova neurona.

- fMRI (funkcionalna magnetska rezonancija) višestrukim snimanjem mozga određuju se razlike registrovanih signala nastale zbog promjena u tkivu.

- MRA (MR angiografija) - tehnika prikaza krvnih žila, uglavnom mozga i vrata.

\section{KONTRASTNA SREDSTVA}

U klasičnoj radiologiji najčešće se primjenjuju pozitivna i negativna kontrastna sredstva. Za snimanja primjenom magnetne rezonantne tomografije koristi se potpuno drugačija vrsta sredstva, (paramagnetne supstance) sa drugačijim hemijskim osobinama i drugačijom dozom i načinom upotrebe. Alergijske reakcija koje se mogu javiti na sredstva koja se primjenjuju u klasičnoj radiologiji (npr. ona sa jodom) nisu kontraindikacija za primjenu kontrastnih sredstava za preglede primjenom magnetne rezonantne tomografije jer ona ima drugačije farmakološke osobine i sastav. Kontrastna sredstva koja se primjenjuju u magnetnoj rezonantnoj tomografiji su paramagnetna kontrastna sredstva.

Jedna od važnih prednosti snimanja magnetnom rezonancijom je osobina dobrog kontrasta između snimljenih tkiva. Taj kontrast se zasniva na različitim relaksacijskim vremenima $\mathrm{T}_{1} \mathrm{i}_{2} \mathrm{~T}_{2}$ koja su karakteristična za svako tkivo. Zbog toga se kontrast može pretežno oslanjati na $T_{1}$ ili $T_{2}$ parametre. Mogućnost mjenjanja jačine kontrasta biranjem različitih TR i TE vremena doprinosi utilitarnosti magnetne rezonance kao radiološke metode. Patološke promjene u tijelu mogu, ali i ne moraju imati različiti kontrast prema normalnom tkivu pa su se zbog lakšeg i sigurnijeg razlikovanja patoloških procesa $u$ zdravom tkivu uvode različita kontrastna sredstva.

Ona su u osnovi paramagnetni joni koji spadaju u grupu prelaznih metala (željezo, mangan, hrom) ili grupu rijetkih metala (gadolinijum). Svi ovi metali imaju stalne magnetne momente $\mathrm{i}$ zbog toga se mogu koristiti $u$ snimanju, ali zbog svoje štetnosti moraju biti vezani na različite nosače. 
Prednost kontrastnih sredstava u snimanju magnetnom rezonancijom je mala količina koja je potrebna za snimanje (reda veličine 10 do 20 mililitara). Zbog toga imamo relativno mali broj alergijskih reakcija nasuprot primjeni kontrastnih sredstava koja se koriste u snimanju kompjuterizovanom tomografijom. Takođe, postoji mogućnost biranja sredstava koja se pretežno izlučuju ili bubrezima ili kroz bilijarni sistem što utiče na povećanje raspona njihove upotrebe. Kontrastna sredstva možemo podijeliti na intravenska ili oralna sredstva koja mogu pretežno djelovati na skraćivanje $\mathrm{T}_{1}$ ili $\mathrm{T}_{2}$ relaksacije.

\section{PREDNOSTI I OGRANIČENJA MAGNETNE REZONANTNE TOMOGRAFIJE}

\subsection{Prednosti MRI}

Glavne prednosti magnetne rezonance u odnosu na druge radiološke metode su:

- Visoka osjetljivost na promjene sadržaja vode unutar tkiva u patološkim stanjima,

- Visoka osjetljivost u otkrivanju tumora, njihovog smještaja i odnosa prema okolini, što pruža bolje informacije o obimu peritumornog edema, krvarenju, nekrozi...

- Savršena vizuelizacija organa koja se približava slikama iz anatomskog atlasa, jer je MRI senzitivnija i rezolutnija metoda od kompjuterizovane tomografije,

- Dobijeni snimci organe prikazuju u sve tri glavne ravni ili njihovoj kombinaciji,

- U toku snimanja ne koristi se rengentsko zračenje i MRI nema štetnih dejstava na organizam, potpuno je bezbolna, komforna i bezopasna metoda,

- Prisustvo vazduha u tijelu i koštane strukture nisu prepreke koje onemogućavaju vizuelizaciju tkiva.

Za razliku od radioloških i metoda nuklearne medicine, koje u dijagnostičkim pregledima primjenjuju opasno jonizujuće rendgenske i gama zrake, magnetna rezonancija koristi samo magnetno polje i radiofrekventne talase, te je sa stanovišta zračenja potpuno neškodljiva. Njome se mogu pregledati i djeca i trudnice, a pregledi se mogu ponavljati više puta pa je pogodna za preoperativne i postoperativne kontrole. I sam aparat je neškodljiv po okolinu, budući da je oklopljen Faradejevim kavezom, pa ne reflektuje nikakva radiofrekventna zračenja.

\subsection{Ograničenja MRI}

Magnetna rezonancija je potpuno neinvazivna i sa stanovišta zračenja neškodljiva medicinska tehnika, ali ipak ima svoja ograničenja. Prije svega, apsolutno je kontraindikovana za pacijente koji nose pejsmejker, jer može da razmagnetiše srčani aparat. Druga opasnost na koju treba upozoriti je eventualno unošenje nekog feromagnetnog predmeta, koji bi vrlo jak magnet mogao da izvuče. U praksi jebilo i dramatičnih slučajeva, poput jednog u Njemačkoj, kada je pacijentu po ulasku u MR istrgnuta očna jabučica jer je u njoj bio čvrsto fiksiran gvozdeni opiljak.

U magnetno rezonantni aparat ne smiju da se uvode ni osobe sa kohlearnimi potkožnim implantima, insulinskim i drugim pumpama, sa takozvanim klipsevima na aneurizmi u mozgu. U ovom poslednjem slučaju bi moglo doći do grijanja aneurizme, opekotina i drugih neželjenih posledica. Radiofrekventni signal povećava temperaturu u ispitivanom objektu, ali u normalnim okolnostima riječ je o minimalnom, za pacijente zanemarljivom povećanju. Svako pomjeranje tijela ometa MR pregled (sliku mogu da degradiraju čak i pokreti crijeva i srčana radnja), pa je pacijente koji iz bilo kog razloga ne mogu da ostanu mirni, ili malu djecu, gotovo nemoguće pregledati bez anestezije.

Kod ispitanika koji ne mogu duže da leže, ili kod onih koji se ne mogu položiti na leđa, MRI snimci mogu biti lošeg kvaliteta. Samo u izuzetno jakim magnetima se dešava da pacijenti ponekad osjete neke senzacije po površini kože ili vide svjetlucanje pred očima. Pregled može biti nekomforan za klaustofobične pacijente, pogotovo zbog dužine trajanja pregleda, ali danas postoje posebne vrste pregleda koje traju samo koliko i zadržavanje daha. Zubni implanti i plombe ne predstavljaju kontraindikaciju za ovaj vid pregleda.

\section{NOVE METODE U DIJAGNOSTICI}

Nove metode $\mathrm{u}$ dijagnostici predstavljene na RSNA (Radiological Society of North America) i obajvljene na ITN (Imaging Tehnology News ).

\subsection{Multikontrastne MRI slike iz jedne akvizicije}

Zasnovana na prvoj MRI tehnici koja ima višestruki kontrast u jednoj akviziciji tokom samo jednog konvencionalnog snimanja. Pomenuta tehnika akvizicije pruža mogućnost modifikacije kontrasta slike nakon završetka skeniranja, što nije moguće kod konvencionalnih MRI. Takođe, pruža se mogućnost generisanja različitih kontrasta u jednom MRI skeneru - uključujući T1, T2, STIR, T1 FLAIR, T2 FLAIR, dual IR, fazno osetljive IR u jednoj akviziciji (Slika. 1).

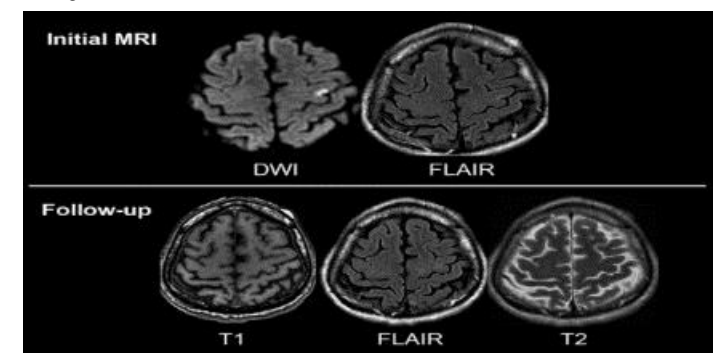

Slika 1. Promjena kontrasta

\subsection{MRI pluća}

MRI pluća je problematičan, jer su pluća ispunjena vazduhom i postoji niska gustina atoma vodonika potrebnih za stvaranje MR slika.

MRI koja je dostupna na sistemu Vantage Titan 3.0T MR, UTE dozvoljava ljekarima da pregledaju tkivo sa vrlo kratkim vremenom relaksacije i regionima visoke osjetljivosti gdje signali uglavnom nestaju prebrzo radi preciznog MRI snimka.

\subsection{Pojednostavljenje i smanjenje vremena za MRI snimanje srca}

Viosworks srčani MRI softver koji pomaže u automatizaciji sekvenci slika za obavljanje punog 3D skeniranja grudnog koša koji uključuje puno kretanje miokarda tokom srčanog ciklusa, protok krvi, vrijeme i 
potpuno automatizovanu kvantifikaciju da nastane ono što GE naziva 7D srčani MRI snimak.

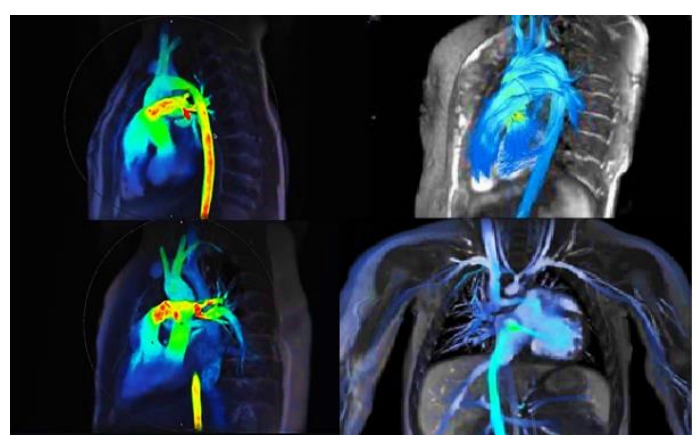

Slika 2. 7D snimak srca

\subsection{MRI i implanti}

Da bi se obezbijedila kompatibilnost sa MRI za pacijente sa kohlearnim implantima potrebno je da implant sadrži magnet koji se može ukloniti. Implanti kohlearnog jezgra su odobreni za rutinsku 1.5T MRI sa i 3T sa uklonjenim magnetom. Postoje kohlearni implanti koji se može podvrgnuti i MRI skeniranju sa $1.5 \mathrm{~T}$ i $3 \mathrm{~T}$, za koje nije potrebna operacija da bi se uklonio i zamjenio magnet prije i posle MRI. ScanWise Implant softver nudi vođeni korisnički interfejs i automatsko očitavanje parametara skeniranja dizajniranih za podržavanje "prvog pravilnog puta" snimanja. Softver navodi operatore da ispune specifične kriterijume za svaki implantat.

\subsection{Poboljšanja kvaliteta MRI snimka}

MDixon sekvenca za snimanje pomaže u pojednostavljivanju i ubrzanju složenih snimanja MRI. MDixon se bavi jednim od ključnih izazova MRI snimanja, to jeste potreba se vide određeni dijelovi anatomije koji su inače pokriveni masnim tkivom što može da bude problem. To se radi sa sekvencama poput SPIR-a (spektralna predsaturacija sa inverznim obnavljanjem) i STIR (kratko-TI inverzno obnavljanje).

\subsection{Tiho MRI skeniranje}

GE Healthcare je predstavio SilenScan MRI tehnologiju za smanjenje šuma i buke u svom Signa Pioneer 3T sistemu, koji ima poboljšani SilentScan paket. SilentScan je dodat za mišićno-skeletno (MSK) snimanje i kičmu, pored kompletnog neuro ispitivanja, koji takođe uključuje difuzno ponderisanu sliku (DWI).

\section{ZAKLJUČAK}

U radu je pokazano da je bio potreban značajan napredak da bi se od osnovnih principa i sekvenci MRI došlo do stvaranja slike ljudskog tijela kao i raznih noviteta na tom polju. Uvedeni su pojmovi značajni za MRI i navedene neke od tehnika koje se koriste pri snimanju ljudskog tijela. U drugom poglavlju je osvrt na ključne elemente implementacije u uređajima za magnetnu rezonantnu tomografiju. Trećem poglavlje govori o kontrasnim sredstvima koja se koriste pri snimanju. Četvrto poglavlje sadrži prednosti i ograničenja, dok peto poglavlje govori o novim metodama $\mathrm{i}$ daljim istraživanjima vezanim za magnetnu rezonancu.
Magnetna rezonanca je suverena, dominantna i nejonizujuća radiološka metoda pregleda, čije su tehnike snimanja obogatile radiološku sliku patoloških stanja organa.

Nove tehnike snimanja, omogućavaju neinvanzivnu identifikaciju bolesnog tkiva $u$ procesu preoperativne pripreme bolesnika, što može bitno da utiče na terapijske odluke u svrhu optimizacije i individualizacije terapijskog pristupa i poboljšanja izvođenja neurohirurške intervencije.

Zbog specifičnih kontraindikacija, malog broja nuspojava i snimanja koje se ne zasniva na jonizujućem zračenju magnetska rezonancija se smatra jednom od najsigurnijih metoda snimanja moderne medicine.

\section{LITERATURA}

[1] Jelena Ećimović: Magnetna rezonantna tomografija, Fakultet tehničkih nauka , Novi Sad 2017

[2] Stark DD, Bradly WG "Magnetic resonance imaging" Unit I. 2nd ed. St.Louis: Mosby Year Book; 1992.

[3] Brown M, Semelka R. MRI: basic principles and applications. John Wiley\&Sons. Inc; 2003

[4] Marckmann P, Skov L, Rossen K et al. Nephrogenic systemic fibrosis: suspected causative role of gadodiamide used for contrast-enhanced magnetic resonance imaging. J Am Soc Nephrol 2006;17:2359-62.

[5] Murata Nozomu, Murata Kiyoko, Gonzalez-Cuyar Luis F.,Maravilla Kenneth, Gadolinium Tissue Deposition in Brain and Bone, Magnetic Resonance Imaging (2016), doi: 10.1016/j.mri.2016.08.025

[6] Xia D, Davis RL, Crawford JA, Abraham JL. Gadolinium released from MR contrast agents is deposited in brain tumors: in situ demonstration using scanning electron microscopy with energy dispersive X-ray spectroscopy. Acta Radiol 2010;51:1126-36.

[7] Kanda T, Ishii K, Kawaguchi H, Kitajima K, Takenaka D. High signal intensity in the dentate nucleus and globus pallidus on unenhanced T1-weighted MR images: relationship with increasing cumulative dose of a gadolinium-based contrast material. Radiology 2014;270:834-41

[8] Michael G. Ambrosia: 7D Cardiac Flow MRI: Techniques \& Automation of Reconstruction, Cleveland State University

[9] https://www.medel.com/us/cochlear-implants-mri-safety

[10] https://www.itnonline.com/article/advances-cardiacimaging-rsna-2016

[11] https://www.itnonline.com/article/advances-cardiacimaging-rsna-2016

\section{Kratka biografija}

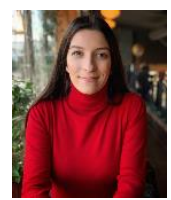

Jelena Ećimović rođena je u Sokocu 1994. godine. Diplomirala je na Fakultetu tehničkih nauka u Novom Sadu, na smijeru Biomedicinsko Inženjerstvo 2017. godine. 